\title{
lowa
}

\section{Streamflow-Data Collection}

One of the most utilized aspects of U.S. Geological Survey (USGS) programs in Iowa is streamflow-data collection and reporting. The USGS operates a statewide network of about 120 gaging stations (fig. 1) and surface-water stage recorders for Federal, State, and local agencies. Streamflow information is used by the National Weather Service during storms to issue flood warnings and forecasts and by the U.S. Army Corps of Engineers (COE) for operating the four Federal reservoirs in Iowa and for commercial navigation on the Mississippi and Missouri Rivers. The Iowa Department of Natural Resources (DNR) and Department of Transportation use streamflow data to monitor the hydrologic conditions of the State, to provide a historical database that is used to develop water-related policy and management decisions, and to design construction projects. Local government agencies use streamflow data for activities ranging from local flood-warning systems used to protect lives and property to providing discharge rates used in complying with wastewater discharge permit requirements. Private citizens and businesses have access to USGS streamflow data.

In addition to the gaging station network, the USGS maintains a statewide network of peak-stage recording gages on small drainage basins for the Iowa Department of Transportation. Data from this program are used to determine floodfrequency and discharge data for the numerous small, ungaged drainage basins in Iowa. Flood-frequency and

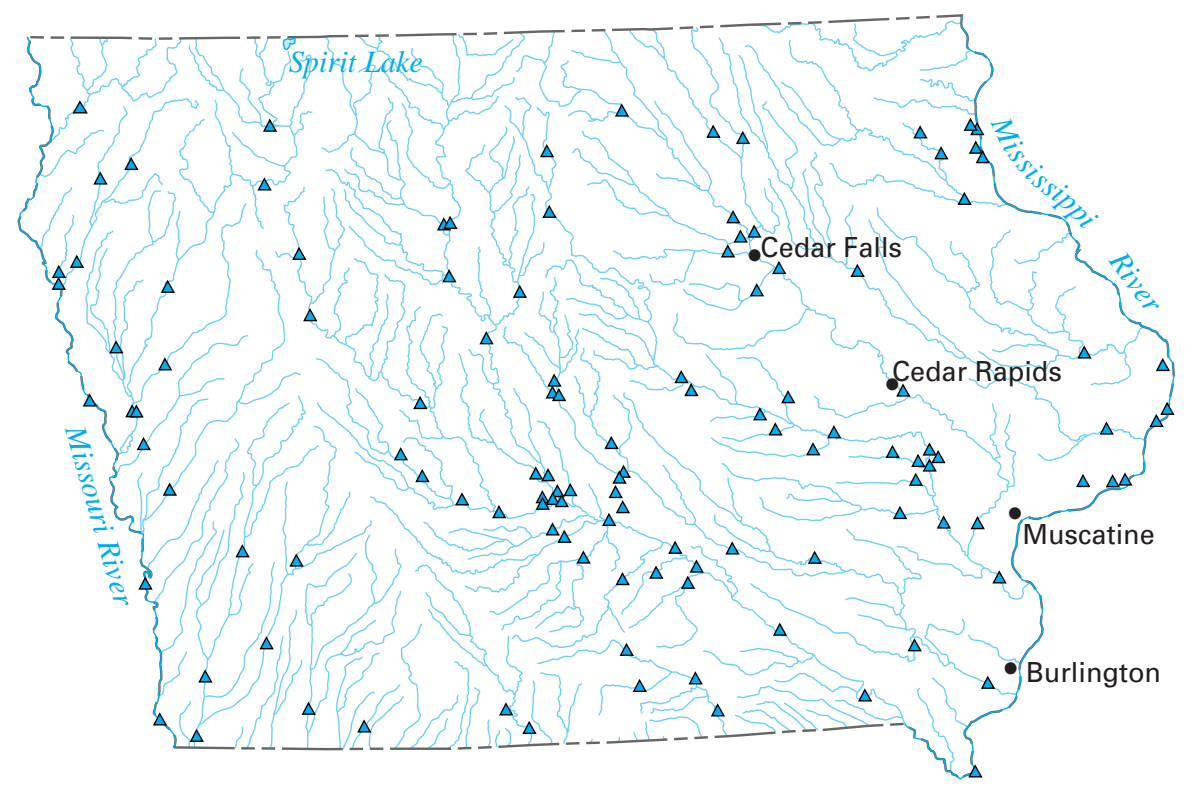

Figure 1. Locations of active streamflow-gaging stations in lowa.

discharge data are used by State and County transportation engineers for designing bridges and other structures.

The most obvious material flowing with the water in Iowa's streams is suspended sediment. Suspended sediment can have serious negative effects for some water users, and it is an indication of the amount of erosion in a watershed. The USGS collects samples and determines the concentration of suspended sediment in water from sites in Iowa. The COE uses the data to provide information on the amount of sediment entering and potentially depositing in Federal reservoirs in Iowa and for the Mississippi and Missouri Rivers because of navigation problems caused by sediment deposition. The Iowa DNR is using sediment data as part of landuse and land-management studies to improve water quality in several watersheds throughout Iowa.

\section{Drinking Water Supplies}

As urban populations grow, communities must obtain additional water supplies to meet their needs. The USGS is studying the availability and quality of ground water in cooperation with several Iowa municipalities.

The USGS is evaluating the alluvial, sand and gravel aquifer along the Cedar River near Cedar Rapids and the Mississippi River at Burlington. The evaluation is focused on determining the natural relationship of the river to the aquifer and how the aquifer is affected by pumping of nearby wells. Studies are underway at Cedar Falls and Muscatine to define areas that contribute recharge to municipal wells. Water managers can use this information to develop plans and policies for protecting the water supply from potential contaminants. 


\section{Flood-Plain Assessments}

The flood of 1993 in the lower Missouri River basin was one of the most devastating in the history of the Nation, and it brought national attention to the lower Missouri River. Flood-plain management is being reexamined in the aftermath of the flooding, taking into consideration alternatives such as setting back levees, acquiring and restoring wetlands, and purchasing flood-plain easements from farmers. Historical channel maps and historical vegetation information are critical components used in assessing flood-plain management alternatives. The USGS is working on making available, in an electronic format, historical maps of the lower Missouri River from Yankton, S. Dak., to the mouth at St. Louis, Mo. This information can be used with other spatial data such as current channel, levees, land cover, public ownership, and levee breaks to evaluate management alternatives.

\section{Evaluation of Restored Habitat}

USGS scientists are working as part of a multiagency cooperative team to assess the successes of prairierestoration projects in the Eagle Lake Wetland Complex in north-central Iowa. Since the late 1980's, wetlands have been restored and perennial grassland has been reestablished on former cropland in northern Iowa under the auspices of the North American Waterfowl Management Plan and its Prairie Pothole Joint Venture. The goal is to reconstruct the prairie lands as functional ecosystems like they were in colonial days. Waterfowl are being monitored through aerial surveys and radiotelemetry studies. Scientists have identified more than 50 species of nongame birds on restored prairie habitats, which represents a diversity similar to that on tall grass prairie remnants in Iowa. These data are intended to be used to assist State and Federal agencies in planning effective prairie-restoration projects, and to modify existing projects to meet prairie-restoration goals.

\section{Effects of Land Use on Water Resources}

The USGS is participating with the Iowa DNR and State and Federal agricultural agencies in studies to determine the effect of changes in land use and management on streamflow and water quality in several small watersheds in Iowa. The primary purpose of this work is to implement best management plans in a watershed and to document the changes in flow and water-quality that result from these changes.

In northeastern Iowa, streamflow and sediment data are being collected from the Sny Magil and Bloody Run watersheds. Sny Magil, a small tributary stream to the Mississippi River, was selected for implementation of improved land-management practices to reduce sediment and nutrient inputs to the stream. Bloody Run is an adjacent watershed being measured for comparison.

Streamflow and sediment data are being collected in the Walnut Creek watershed in central Iowa. Much of the Walnut Creek watershed is included in a recently established National Wildlife Refuge. Refuge managers eventually will convert much of the formerly intensively farmed land in the watershed to a restored prairie. This conversion of land use offers a unique opportunity to determine its effect on streamflow and suspended-sediment concentrations at a scale not often available for study.

\section{Ground-Water Resources}

Ground water is the primary source of drinking water for Iowa's population. Information is needed by State and local governments to understand trends in water levels and water quality in the principal aquifers and to develop policy and management decisions related to their use. The USGS collects and compiles waterlevel data from a statewide network of about 150 observation wells in cooperation with the Iowa DNR. Information from this network also is used by local governments and individuals requiring information on the depth to and availability of ground water at specific locations throughout Iowa.

A statewide program of ground-water sample collection and analysis for the principal aquifers in Iowa is operated by the USGS in cooperation with the Iowa DNR and the University of Iowa Hygienic Laboratory. Data from this program are used by State agencies to track trends in water quality at various locations and depths throughout Iowa and to respond to undesirable concentrations of specific chemicals, such as pesticides, through policy and management decisions.

\section{Spirit Lake: Food Supply and Demand in an Important Fishery}

USGS scientists are assessing the balance between food supply and demand in Iowa's most popular lake fishery, Spirit Lake. Working with the Iowa DNR, USGS scientists are using various techniques to assess the abundance and dynamics of forage fishes, and their capacity for supporting game fish. Concurrent work on game fish species such as walleye, northern pike, largemouth bass, smallmouth bass, and others is providing estimates of species abundance and information on the demand and type of forage consumed (fig. 2). 


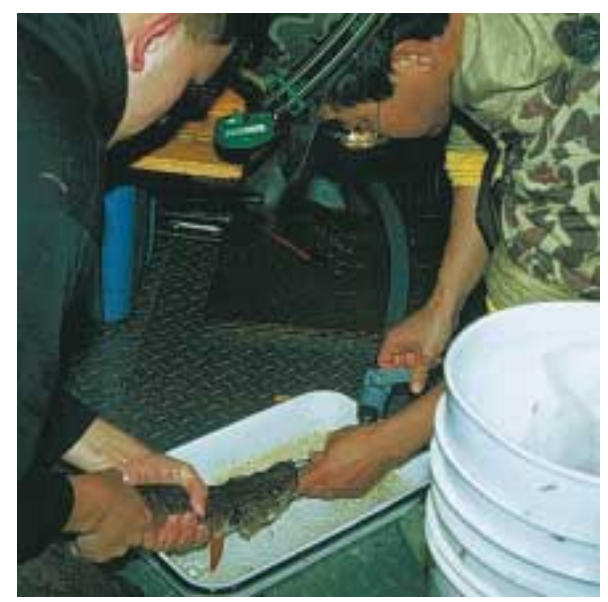

Figure 2. A northern pike being sampled to determine the type of prey items it ate.

\section{Reducing Deer-Vehicle Collisions}

USGS scientists are evaluating the effects of land use on the incidence of deer-vehicle collisions in Iowa. These collisions are a significant problem for the State, as they are nationwide. In 1991, 538,000 deer-vehicle collisions occurred along public highways in the United States. These accidents caused death and injury to motorists (and deer) and extensive vehicle damage. The USGS has developed a geographic information system for Iowa that includes road systems, river corridors, urban areas, public lands, and landscape cover where deervehicle accidents have occurred. These data are used to determine the land-use and habitat characteristics that have high probabilities for deervehicle collisions. Models developed from this study are intended to provide highway and land-use planners in Iowa and elsewhere the information needed to reduce deervehicle collisions and increase motorist safety.

\section{National Water-Quality Assessment}

The Eastern Iowa Basins study being conducted by the USGS as part of the National Water-Quality Assessment
Program (NAWQA) has completed the initial intensive data-collection phase of implementation (1996-98). The goals of the program are to describe the status and trends in water quality of selected areas throughout the Nation and to identify factors that affect their water quality. The Cedar, Iowa, Skunk, and Wapsipinicon River Basins are being studied in Iowa. Reports summarizing data that have been collected and findings of the study are being prepared.

\section{Mapping Partnerships}

The USGS has been cooperating with the Natural Resources Conservation Service (NRCS) and the Farm Service Agency to produce digital orthophotoquads (DOQ's) for Iowa. DOQ's are scanned aerial photographs in which distortion and displacements caused by the camera orientation and terrain are removed. A DOQ may be loaded into a geographic information system and used with other data for analysis and geographic applications. The NRCS has been using the DOQ's as a base to digitize the soils layer. Other applica- tions of DOQ's include collecting and updating land use and land cover, natural resource inventory and mapping, delineating field boundaries, and planning applications. Two thirds of the State of Iowa has DOQ coverage or DOQ's scheduled for production.

The USGS, with the support of State and local agencies, is producing digital elevation models (DEM's) for the State of Iowa. DEM's are sampled arrays of regularly spaced elevations used for depicting topography. The high resolution DEM's can be used for hydrologic modeling for flood analysis, streamflow dynamics, and hazard mitigation.

\section{Ice-Age Winds Recorded in Loess Deposits}

Cooperative studies between the Iowa DNR-Geological Survey Bureau and the USGS have resulted in new insights about ice-age climates. Loess is a windblown silt that forms some of the most agriculturally productive soils in the world (fig. 3). Because loess was deposited by the wind, it is

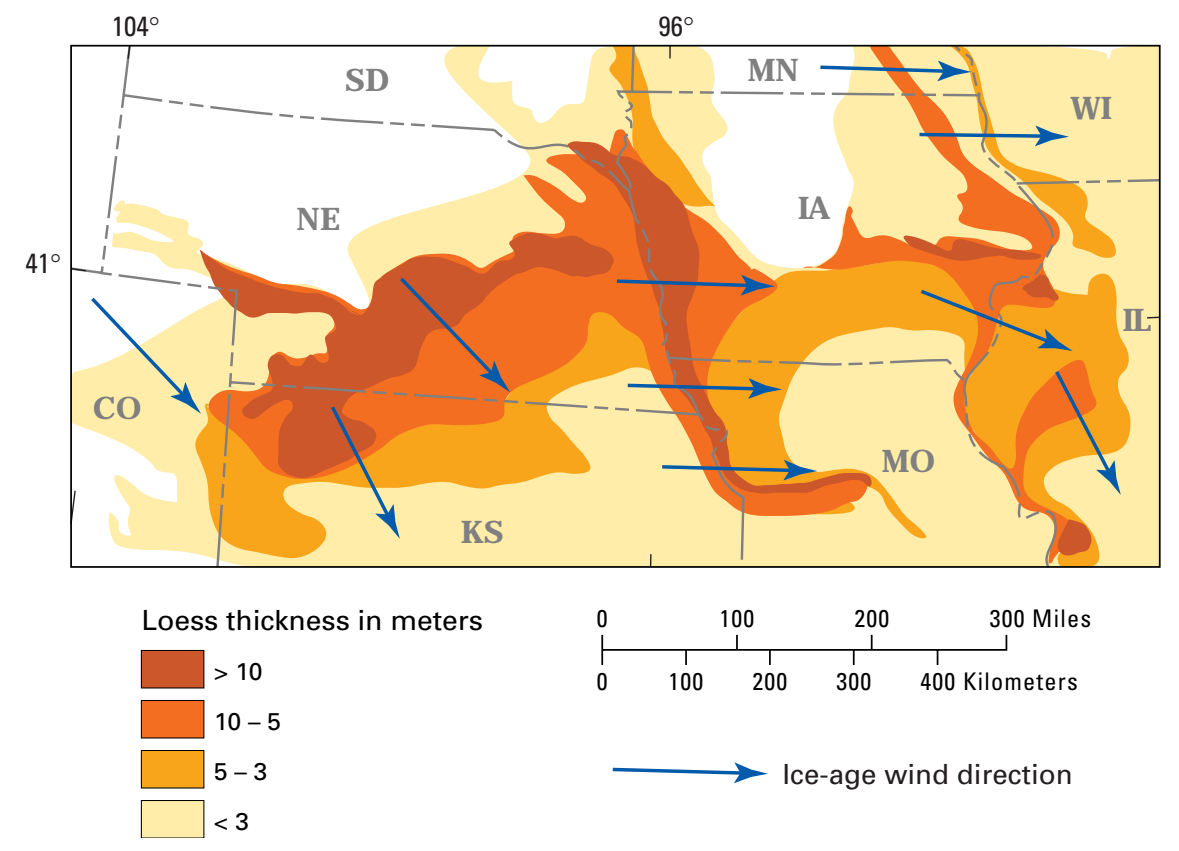

Figure 3. Loess map of lowa and surrounding region. 
a direct record of atmospheric circulation, and, therefore, it can be used to test computer models of ice-age climates generated by atmospheric general circulation models (AGCM's). Chemical and sediment studies and AGCM simulations of climate indicate various directions of prevailing winds in Iowa during the last glacial period. Geologic studies of loess deposits in Iowa are useful for calibrating computer models of past climates and verifying the conclusions of these models.

\section{lowa Soils and Carbon Cycling}

The USGS has inaugurated the Mississippi Basin Carbon Project to understand the role of erosion and deposition in carbon cycling and carbon dioxide emissions. In Iowa, a field study of the historic, interactive exchange of eroding topsoil, carbon and nutrient loss, and carbon and nutrient replacement is underway with the cooperation of U.S. Department of Agriculture-Agricultural Research Service, U.S. Department of
Agriculture-Natural Resources Conservation Service, Iowa Department of Natural Resources, and Natural Resources Ecology Laboratory at Colorado State University. Historic reconstructions of soil erosion, transport, and soil organic carbon are based on measurements of organic carbon, nutrients, and several isotopes. These measurements are being systematically conducted on a pair of pristine and cultivated hillslopes to assess the change between presettlement and modern conditions (fig. 4). These changes by erosion profoundly affect soil carbon and nutrients and, thereby, also affect carbon dioxide emissions.

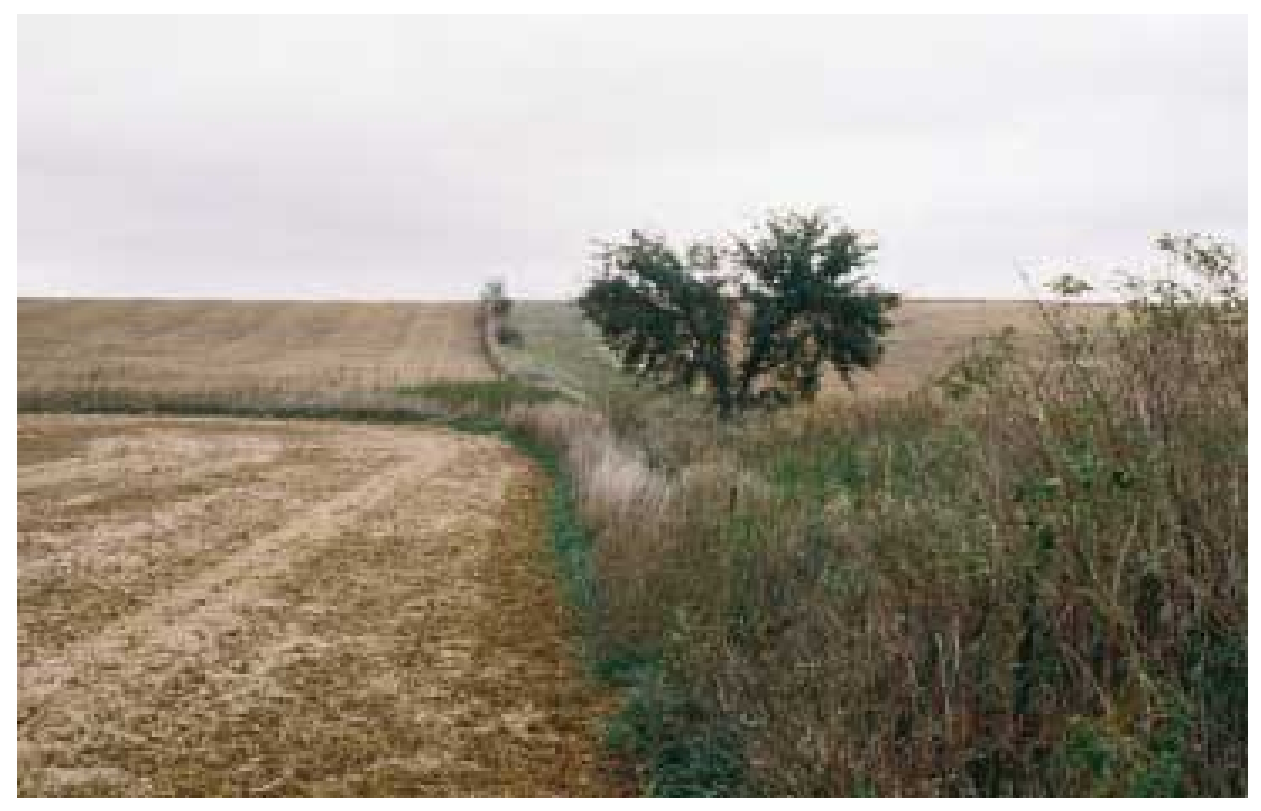

Figure 4. Cultivated land adjacent to native prairie.

USGS office locations

The USGS has 70

employees in lowa

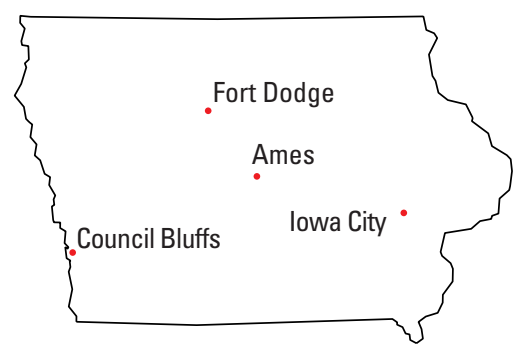

USGS State Representative

Federal Building, Room 269

P.O. Box 1230

400 S. Clinton St.

lowa City, IA 52244

(319) 337-4191

FAX (319) 358-3606

USGS Home Page:

http://www.usgs.gov

Reports and products:

1-888-ASK-USGS 